\section{Elżbieta Małgorzata Obara}

Pontificia Università Gregoriana, Rzym

elzbietao@tiscali.it

DOI: http://dx.doi.org/10.12775/BPTH.2019.021
Biblica

et

Patristica

Thoruniensia

12 (2019) 4: 395-408

ISSN (print) 1689-5150

ISSN (online) 2450-7059

\title{
The pathos of the Accusation
}

\section{Analysis of communicative strategy in Is 57,3-13}

"My word will not return to me without effect," says YHWH in Is 55,11. "Saying is doing," affirms Plato ${ }^{1}$. In saying, one does things ${ }^{2}$. In discourse, in fact, phrases do not simply describe the act of doing, but really do. In every use of language there is present the performative element, and this is sought out, interpreted, and evaluated. The implications that this simple observation has on biblical hermeneutics are perceptible: if fiction and poetry can open everyday reality to new possibilities of being, all the more is such communicative and performative potential decisive in the biblical text.

In Is 57,3-13, the reader is called to confront a passionate discourse of God that concerns precisely this hermeneutical dimension. It is YHWH who speaks and every phrase of his takes part in a communicative process whose finality is not at all informative, but decisively performative. The literary genre of this text and the intentionality of its application have not always been taken into adequate consideration. It is not enough, indeed, to discover here a generic form of judgment, because Old Testament literature provides for two procedures that are distinct and complementary to resolve conflicts over questions of rights: mišP $\ddot{a} t$ and rîb. Even if the reestablishment of the violated right be the object common to both, the two procedures differ significantly.

The term mišpät indicates judiciary proceedings that unfold in the tribunal, at the "gate" and before judges (persons who possess authority, elders, priests, or the king) who have the duty to pronounce sentence that condemns the guilty and absolves the innocent. In this case, one may speak of a "legal" or "judiciary case" or presided over by a judge.

1 Plato, Cratylus 387b.

2 J.L. Austin, How to Do Things with Words; J.R. Searle, Speech-Acts. An Essay in the Philosophy of Language. In the field of biblical studies, cfr. M. Grilli, M. Guidi, E.M. Obara, Comunicazione e pragmatica nellesegesi biblica. 
In the rîb, as "juridical dispute" or "juridical controversy," there is not foreseen the intervention of a "judge"; the place of its unfolding is not the tribunal and does not conclude with the pronouncement of sentence. In the case of the $r i ̂ b$, the one who feels that a right of his, natural or acquired, has been violated addresses directly the defendant in a direct accusation, stigmatizes the reprovable action, and threatens sanctions with the scope of pushing the accused into recognizing his own fault and to put into action corresponding attitudes so that one re-establish the broken relationship according to truth and in justice ${ }^{3}$.

With this characteristic articulation of accusation and sanction, and with its purpose of reconciliation, the procedure of the rîb is the conceptual framework of Is 57,3-13. God represents the injured party who initiates the fight on the juridical grounds of mutual belonging that binds him to Israel. He perceives as a grave injustice the violation by his people of this filial and spousal relationship. The purpose of his way of proceeding is not, though, simply the announcement of a clear and definitive condemnation, but the recovery of the relationship itself. This scope determines the communicative form of the divine discourse, which from its first strokes is anything but neutral. The one who wants to get his beloved partner back, despite the fact that they have been unfaithful, speaks by putting into action every persuasive strategy. YHWH does not become an exception to this: even he keeps silent and speaks, insults, accuses, threatens, and entices for a return, revealing his willingness to forgive.

The articulation of this divine discourse in Is $57,3-13$ follows the steps typical of a bilateral contest:

Convocation and organization of the accusation: vv. 3-5

Threat: v. 6ab

Impossibility of resigning to the facts: v. $6 \mathrm{c}$

Reprisal of the accusation: vv. 7-11

New threat of sanction: v. 12-13a

The true path toward reconciliation: $\mathrm{v} .13 \mathrm{~b}$

\section{The convocation and organization of the accusation: vv. 3-5}

3 Now you, draw near here, children of the seductress, race of an adulterer and of a prostitute!

3 Cfr. Gn 13,6-12 Abram and Lot; Gn 26,10 Abimelech and Isaac. 
4 (a) In whom do you delight [make fun]?

(b) Toward whom do you widen your mouth, stretch out your tongue?

(c) Are you not rebellious children, lying race?

5 Stimulating yourselves between the terebinths, under every green tree, immolating children in the valleys, in the fissures of the rocks.

In v. 3, with the directive act (impv. קרבו ), God, as the injured party, begins the contest. Those convened are named through two metaphors: that of children (vv. 3-4) and that of the adulterous woman (vv. 6-13a). Both metaphors imply the same referent, the people of Israel, or a part thereof, caught in violation of two types of relationship with YHWH: that of sonship and that of a spousal kind.

The metaphorical covering chosen is not random and does not serve only the portrayal of the betrayal; it evokes a relationship of love, of exclusivity and of reciprocal belonging, without which the betrayal could not even exist. Love shows itself to have two faces: the one violated and outraged of the unfaithful, and the one wounded of the betrayed, which, nevertheless, by virtue of love, rebels against the betrayal. As unfaithful love pursues all the avenues of betrayal, so the wounded one does not give up and seeks all the ways of persuasion to convince the unfaithful one to retrace his steps. God, therefore, in this apparently violent convocation, expresses the pathos of his love, comparable according to human measures - to that of a father and of a husband. If God were not still profoundly "enamored" he could not invoke the rîb against the unfaithful children and spouse.

Verse 4 is composed of three questions of a rhetorical character and should be interpreted as acts of accusation ${ }^{5}$.

The first question, על-מי תתענגו, is often intended as an expression of a mocking and derisory attitude towards YHWH ("Of whom do you make fun?"). Inreality, in its usual meaning, the root ענג expresses positive theological content: "find delight/joy/pleasure" in the Lord'. In the case of Is 57,4, the first of two interpretations is possible, but the sarcastic tone of the question-accusation

4 The directive act is that which the speaker uses to ensure that the listener do something in the future, as when, for example, he asks, challenges, commands, insists, pleads. To define the illocutionary forces of linguistic acts, we use the nomenclature of J.R. Searle. Cfr. E.M. Obara, "Le azioni linguistiche," pp. 83-117.

5 For the function of accusation in rhetorical questions, cfr. Gn 3,13; 44,15; Ex 2,13; Is 1,13 etc. Cfr. also H. Lausberg, Handbuch der literarischen Rhetorik, pp. 379-384; P. Bovati, Ristabilire la giustizia, pp. 64-66.

6 Cfr. Sal 37,4; Gb 22,26; 27,20. 
addressed to the unfaithful leads one to prefer the second: "In whom do you delight?" The characterization of those interpellated in vv. 3-4 and their actions, mentioned in what follows in the discourse, demonstrates that their true delight is not in YHWH, but in the devious practices with which they seek to gain the graces of other gods.

The gesture of "widening the mouth" mentioned in the second question can express a hostile or mocking attitude (cfr. 1 Sam 2,1; Ps 35,21) reserved for the Lord. It could even contain an image in itself positive, of one who prolongs his pleadings and ardently desires to be satiated with the good things of $\mathrm{God}^{7}$, but in this case it would be utilized in an ironic manner since, in reality, those praying seek the repayment of their desires not in God, but in idols, and to these they address their pleas.

With the third rhetorical question ("Are you not?") ${ }^{8}$, God reaches the climax of the accusation and emphatically affirms that they, precisely, the children, are rebels and liars.

In v. 5 , the divine speaker demonstrates that the representative force of his affirmations is borne witness to by a constant behavior of the accused ("Stimulating [consoling] yourselves between the terebinths, under every green tree, immolating children in the valleys, in the fissures of the rocks") ${ }^{9}$. The emotionally charged and passionate language draws one's attention: God does not report the list of facts in a neutral way, but makes transparent the disgust and the bewilderment that such facts necessarily provoke. And thus, the participle refers to an intense emotion (חנחמים (חמם aroused by a cultic action or by attainment of a consolation there sought out (נחם), but simultaneously makes transparent a sarcastic vein suggested by the similarity of the verb חמם with wa which expresses the being in heat typical of animal copulation ${ }^{10}$. Evoking the child sacrifices associated with the cult of Molech, God does not make use of

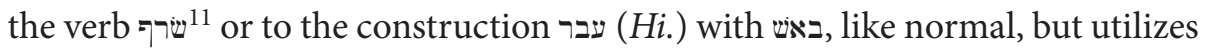

7 The nouns לשון andicate, by metonymy, the act of speaking and its content (cfr. Jb 33,2; Zc 14,12) and the verb ארך (Hi.), considered in its temporal sense (cfr. for רחב with פ in Ps 81,11 means to open the mouth to be satiated by the Lord.

8 Cfr. H.A. Brongers, "Some Remarks on the Biblical Particle hâ 10 ”", pp. 177-189.

9 The representative act is that in which the speaker undertakes to sustain the truth of a proposition, or in the realization of something; for example, when one affirms, explains, laments, believes, concludes, negates, refers.

10 Cfr., for example, Gn 30,38-39. The only exception is Ps 51,7, where the verb is used for the human embrace characterized, though, by sinfulness.

11 Cfr. 2 Kgs 17,31; Jer 7,31-32; Jer 19,5-6. 
the verb שח, characteristic of the preparation of licit sacrifices to $\mathrm{YHWH}^{12}$, and signals thus something aggravating in the effrontery of the illicit behavior.

Here, therefore, is the gist of the divine accusation: you, who have been made children, do not behave as such before me. Your fondness is not for to me; on the contrary, through your idolatrous behavior, you demonstrate your rebellious temperament, aggravated by arrogance and insolence.

\section{Threat: v. 6ab}

6 Between the stones of the torrent your portion, these indeed are your inheritance;

${ }^{6 b}$ given that for them you have poured out libations, you have presented offerings.

In v. 6a, God pronounces authoritatively and in accord with truth upon the effect, inevitable and sure, of the attitude of the accused just exposed (the representative act). Such an assertion, in the context of the rîb, serves as a threat through which the speaker seeks in influence the behavior of his interlocutors.

In Is 57,6a, the parallel arrangement of the elements demonstrates that the inheritance (חלק) and the portion (גורל) of the unfaithful consists in the "stones of the torrent" (חלקי-נחל). If one accepts the interpretation ${ }^{13}$ according to which חלק III, "die" or "be destroyed" and נחל consists of the root considered a place of burial ${ }^{14}$, then one comes to affirm that the inheritance and the portion of the unfaithful is found among the dead. In fact, the same cadavers buried in the wadi, "these indeed" (הם הם), constitute the foreseen inheritance. In this way, in the place of cohabitation and communion with the Lord of life ${ }^{15}$, for the accused is foreseen a lot shared with the dead.

12 Cfr. the Passover prescriptions (Ex 12,6.21; 34,25), those related to the holocaust ( $\operatorname{Lv} 1,5.11)$, to the offering of communion ( $\operatorname{Lv} 3,2.8 .13)$, to the sacrifices for sin ( $\operatorname{Lv} 4,4.15 .24 .29 .33)$, to expiatory sacrifices $(\operatorname{Lv} 6,18)$, to sacrifices of reparation $(\operatorname{Lv} 7,2)$, in the rites of the consecration of the priests (Ex 29,11.16.20; Lv 8,15.19.23).

13 Cfr. W.H. Irwin, “The Smooth Stones”, pp. 31-40; T.J. Lewis, Cults of Dead in Ancient Israel and Ugarit, pp. 158-160. For a discussion on this point, cfr. also K. Spronk, Beatific Afterlife in Ancient Israel, pp. 231-233; 247-250.

14 Cfr. 2Re 23,6; Ger 31,40; Gb 21,33; 2Re 23,10.

15 Cfr. Is 57,6a; God is a refuge of the one praying in Ps 16,$5 ; 73,26$; 142,6; Jer 10,16; 51,19; in Lam 3,24 is Yhwh the portion of the faithful. 
The "stones of the torrent" (חלק I) recall also the stones used in the drawing of lots: in this case the inheritance of the stones constitutes an ironic counterpart to the inheritance of the fertile earth guaranteed by divine generosity (cfr. $\mathrm{Nm}$ 26,53ss.; Josh 18,10). Finally, the mention of the stones is an effective allusion to the lapidation prescribed as punishment for necromancers and diviners (Lv 20,27) and in the case of offerings of children to Molech (Lv 20,2).

All together, the lot here represented evokes in a sarcastic way the theme of the principle gifts of YHWH: the earth becomes an impure place of burial and descendence is made up of cadavers. The stones for drawing lots are the only heritage and these are nothing other than an instrument of death. In this way, the speaker strikes his interlocutors in their deepest expectations, since they are rooted in the history of Israel from the promises to the patriarchs.

Such a representation, though, lets the pathos of God shine through and serves, in effect, to exercise a paternal admonition before these children: in the case in which the repugnant aspect of illicit behavior alone does not result in a sufficient reason for pushing the people to change their attitude, there could factor the fear of ominous and inevitable consequences.

The participle a in v. 6b ("given that") signals the logical connection between the outcome (v. 6a) and the behavior that determines it (v. 6b: "for these you have poured out libations, you have presented offerings"). Tying together in such an evident way the outcomes and the behaviors of the idolators, YHWH confirms that he is not responsible for the catastrophic situation hanging over his interlocutors, but their personal, operative choices, the only ones, therefore, able to overturn the outcomes.

\section{Impossibility of resigning to the facts: v. $6 \mathrm{c}$}

\section{${ }^{6 c}$ Could I be consoled for this?}

Verse $6 c$ produces a certain disequilibrium in the course of the rîb; nevertheless, precisely because it is outside of the pre-established schema, it indicates a particular orientation of the communicative force of the divine discourse. It does not seem that the communicative function of the phrase has been, up to now, taken into adequate consideration by interpreters ${ }^{16}$.

16 Two interpretations above all are representative. The first (for example, by G.J. Polan, In the Ways of Justice, p. 134) sees here an expression of God's disgust because the illicit practices cannot constitute consolation. The second (for example, per E.J. Young, The Book of Isaiah, III, p. 403) retains that this is a rhetorical question about whether idolatrous acts 
The phrase "Could I be consoled for this?" is an expressive ${ }^{17}$ act through which YHWH manifests his feelings caused by the disgusting actions of the unfaithful (v. 6b), but above all because of their tragic lot signaled by death (v. 6a). As someone does not find consolation after the loss of a person dear to him, thus YHWH can never be consoled for those children who are no more ${ }^{18}$ : those rebellious and lying children (v. 4) who are no longer children of God but of an adulterer, of an enchantress and a prostitute (v. 3); those who have broken ties with the God of life and become destined to find themselves under the dominion of death (v. 6a).

With the rhetorical question, therefore, YHWH affirms strongly that he could never be consoled by the "death" of his children and by separation from them ${ }^{19}$, exactly as is spoken of Rachel in Jer 31,15 ("Yes, there is heard a voice in Rama, a lament, a bitter cry; Rachel cries for her children; she refuses to be consoled for her children, because they are no more" ${ }^{20}$ ). The expressive meaning of the phrase gives the decisive mark to the goal of the divine proceedings in Is 57,3-13 that, all together, do not have as their scope a definitive condemnation, but on the contrary, make it that the ties do not break altogether, that the "children" do not precipitate into an irreversible state.

The impossibility of God to resign himself to the facts, to give up, justifies the impassioned reprisal of the accusation beginning in v. 7 .

\section{Reprisal of the accusation: vv. 7-11}

7 On a high and elevated mountain you have placed your bed; you have even ascended there to offer sacrifices.

8 Behind the gate and the jambs you have placed your memorial, hence far from me you have uncovered your bed, you have ascended there, you have widened it, and have negotiated to your advantage with those with whom you have loved to lie down, you have enjoyed the heritage.

can satisfy God and urge him to mercy, or if these do not demand, rather, revenge (ם $\mathrm{Ni}$. can indicate a kind of repentance of Yhwh, a rethinking with respect to his purposes).

17 The speaker expresses a certain psychological disposition with respect to a state of things; for example, when he asks pardon, deplores, congratulates, thanks, gives welcome.

18 About the meaning of consolation in the context of struggle expressed with the verb נחם (Ni.), cfr. Gn 24,67; 38,12; 2 Sam 13,39; above all Jer 31,15.

19 The imperfect expresses in this case the abilitative modality that, with negation, indicates the incapacity or impossibility of doing something.

20 The verb נחל Ni. with. 
9 You have descended to Molech with the oil, you have multiplied your perfumes, you have sent your sacrificial offerings to afar, you have lowered yourself as far as Sheol.

10 In your long journey you have grown tired, but without saying, "It is useless." Your vitality you have found again, for which you do not feel weak.

11 Of whom were you afraid and whom did you fear that you needed to lie so? Meanwhile you did not remember me, you took no care.

Have I not remained silent for a long time? But of me you have not been afraid.

The prolonging of the accusation in vv. 7-11 demonstrates that the possibility of reconciliation is still open. God uses new means to convince the one who is unfaithful of repugnance for his conduct and to lead him to a new relationship that is just and truthful.

First of all, the speaker changes the metaphorical framework and, comparing the defendants to an adulteress, shifts the focus from the relationship of sonship to a spousal one. Paradoxically, with recourse to the humiliating metaphor of the harlot, God seeks to renew in the accused "woman" the memory of her true identity and, at the same time, reveals the depth of his wounded love.

Recourse to the metaphor of the adulteress explains the bulky presence of expressions that refer to illicit sexual activity to represent the betrayal of God by the people. Transgressions of a sexual nature interweave with those belonging to the cultic environment: affection and hope of life originally directed toward YHWH become thus shamelessly "parroted" to ingratiate idols, even when it has to do with the sovereigns of death. The effect is that the portrayed practices end up not only illicit, but also devious and repugnant. The tone of the denouncement is, at the same time, sorrowful and sarcastic, characteristic of wounded love.

In v. 7, a caricature image denounces, as in the illicit and adulterous cultic act YHWH is betrayed even on his holy mountain ${ }^{21}$ and on the altar of the temple ${ }^{22}$.

With his behavior, the adulteress manifests the rejection of the memory of YHWH and of his salvific acts (v. 8 "Behind the gate and the jambs you have

21 In the isaianic corpus the "mountain" usually evokes Mount Zion, the place par excellence of the presence of God: Is 2,2 ("house of God"); 2,3 ("temple of God"); 8,18 (dwelling of God); 18,7 (place where the name of the Lord is found).

22 The adverb שם referring to the "bed" (cfr. Gn 49,4), mentioned lately. 
placed your memorial"). The זכרון is understood as a "historical memory" ${ }^{23}$. To place the memorial itself "behind the gate and the jambs" expresses forgetfulness and contempt and is the attitude opposed to that asked for in Dt 6,6-9 and 11,20 , to inscribe on the gates and on the jambs the "words," identifiable with the "memorial" of the people of Israel (cfr. also Ex 13,9 and Dt 6,8). What is more, the lexeme זכרון, associated with a possessive pronoun, alludes also to the identity of the prostitute herself; in fact, whoever disavows his own historical memory shows contempt and, in the end, loses his own identity.

The acts described in what follows in v. 8 derive from the forgetfulness of one's own identity and of the rupture of the relationship with God: to uncover the bed, get up on it and widen it is to give oneself to acting like a prostitute to welcome all others outside of the Lord ${ }^{24}$. The locution ותכרת-לך מהם evokes, probably, the stipulation of a treaty ( 1 Sam 20,$16 ; 22,8$; $1 \mathrm{Kgs} 8,9$ ) or of an accord (cfr. 1 Sam 11,2) through which a woman seeks to obtain a personal benefit (the complement of advantage לך). And while love is a constant implied in the covenant with YHWH (Ex 20,6; Dt 6,5; 7,9; 10,12; 11,1), the locution mentions expressions of love from a woman directed to other gods.

At the conclusion of v. 8 is expressed the purpose of the actions of the prostitute. The meaning of the locution יד חזית is not immediately understandable; it is, however, possible to attribute to the verb חזה the meaning "provide" or "ensure" (cfr. Ex 18,21), or the more usual meaning, "contemplate," with the nuance of "experience" ${ }^{25}$ or "enjoy" ${ }^{26}$. In these cases, one speaks of the prostitute who, in her mind, is convinced (חזה in the Perf.) of having reached the goal or, after having followed through her objective, contemplates or enjoys its possession. The objective is indicated by 7 , which has a wide range of meanings. As in Is 56,5 - where the noun means participation in salvation obtained, as a theological and metaphorical expression of material inheritance - also in Is 57,8 refers to the fruits of salvation. And yet in Is 56,5 these are the gift of $\mathrm{YHWH}$; in the case of the prostitute these are an illusory mirage resulting from one's own efforts.

23 In various texts, זכרון is tied to a tangible sign (offering, particular object, etc.) and, however, refers to historical events like, for example, "the memorial between the eyes" in Ex 13,9, which has the scope of recalling liberation from Egypt; "the memorial that recalls a fault" in Num 5,15; in Josh 4,7, the stones that recall the crossing of the Jordan, etc.

24 The verb (Pi.), not accompanied directly with any object, contains a certain ambiguity; it is more opportune to consider משכבץ as the object of all three verbs.

25 Cfr. Is 26,11.

26 Cfr. Ps 27,4. 
According to Is 57,9, the prostitute descends to reach Molech ${ }^{27}$, bringing oil, a good that ought to be destined, instead, for YHWH (cfr. Gn 35,14; Ex 27,20; $30,31)$. Jacob pours the oil to honor God who reveals himself through words of blessing and assurance of protection $(\mathrm{Gn} 28,18)$; the woman, instead, with oil venerates a god that she believes has benevolently revealed himself to her

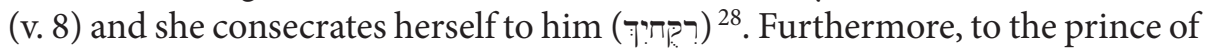
the subterranean kingdom she sends "messengers," identifiable plausibly with the same offerings of infanticide, and she herself abases herself unto Sheol, the place of the kingdom of death, in a sacrilegious gesture (שפל) of humility with respect to the lord of death and not to the Lord of life. The woman, in short, "tires herself" (v. 10) in her illicit trafficking, without admitting their "uselessness" (נואש) 29, like a madwoman who thinks she's obtained, by her own efforts, the blessing of life (חית ידך מצזא), even bestowing honor on the lord of death.

Verse 11 constitutes the conclusive moment of the accusation and offers a key to reading it, showing how fearing and venerating whomever is not God coincides, ultimately, with the abandonment of YHWH. On the communicative plane, the mention of the lie (כי תכזבי) occupies and important position. In the end, in the moment in which one puts aside the memory of one's own origins and of his own identity as child and spouse, and when one takes refuge in the vortex of abominable actions to find salvation with whoever is not in possession of it and is not in a position to offer it, one falls into unbecoming selfdeceit. One lies even to YHWH, holding him incapable of understanding and of revealing the truth of actions that express insincerity and abandonment of the covenant (cfr. Ps 78,36-37; Hos 7,13ff.). The veneration of other gods leads to that crazed attitude of needing to lie (תכזבי of assertive epistemic modality of the Impf.) and leads to death (Is 28,15). Forgetting the Lord develops inevitably into sin and falsehood (Zech 3,13), also because this coincides with adhesion to idols, who are nothing other than "falsehood" (Is 44,20; שקר, Am 2,4; YHWH being the only foundation of truth (Num 23,19).

By and large, therefore, the purpose of the accuser is revealed here, who does not enjoy unmasking the misdeeds of his defendants, but who uses every

27 The form שור ii, "go down," "descend," because of its correspondence with the descent to hell, evoked in the last part of the verse.

28 The construction ריקח is a hapax in the HB; the root חקר, nevertheless, is well-attested in reference to the production of incense (Ex 30,35) and of ointments, in particular the oil destined for the consecration of the meeting tent, the ark, the sacred utensils and the priests (Ex 30,22-31). Its preparation for improper uses was severely prohibited and was punished with banishment from the people (Ex 30,32-33).

29 The construction composed of the verb אמר followed by the Ni. participle of the verb יאש found in Is 57,10; Jer 2,25; 18,22. 
means at his disposal to push his own interlocutors into assuming, in a responsible way, the truth of themselves, so that this revelation might be recomposed in truth and justice.

\section{A new threat of sanction: v. 12-13a}

12 (a) I will proclaim your justice and your works, (b) and they will not be to your advantage.

13a At your cry let your idols save you! All of them the wind will carry away; the breeze will take them.

The conclusion of the accusation provokes a change in persuasive strategy. In v. 12a, with a commissive act ${ }^{30}$ (איד), God undertakes to act in the future by solemnly notifying the misdeed of the woman, her "justice and her works" ${ }^{31}$. The emphatic pronoun אני underlines that, instead of fearing and revering idols, the woman ought to have feared YHWH (v. 11), the only one who possesses authority and the power to reveal the true nature of things and to sanction their value. This has to do with a last and powerful threat directed to the defendant, because her present handiwork does not allow her to hope in a salvific manifestation of God: the justice and the works of the woman cannot be to her advantage (the abilitative modality of the Impf. לא יועילוך). Recourse to litotes impresses upon the pronouncement a greater expressive force and an ironic tone: this "justice" and these "works" themselves will bring sentence ${ }^{32}$.

That the destiny of the adulteress will have tragic repercussions is confirmed in v. 13a by her cries in seeking help (בזעקך (ביד) ${ }^{33}$. Such cries cannot obtain a positive response (the jussive of precative modality, is sarcastic), because

30 With a commissive act the speaker undertakes, in various ways, to assume a certain kind of conduct in the future, to execute a certain future action; for example, when he guarantees, promises, swears, makes a vow.

31 Both terms express in an ironic sense (antiphrasis) the handiwork of the prostitute and of her progeny, as they thus appear in the discourse. Because of the particle normally indicating the direct object, it is preferable to consider the verb נגד as governing both elements מעשיך and צמש משיך.

32 From the pragmatic point of view, this type of threat is indispensable in the proceedings of a bilateral contest because it clarifies the real power of the accuser in effecting even a grave punishment. Cfr. P. Bovati, Ristabilire la giustizia, pp. 70-77.

33 Cfr. Ex 2,23; Neh 9,28; Ps 107,13.19. Cfr. also K. Pauritsch, Die neue Gemeinde, p. 65, which specifies what describes a call by one who seeks a savior (Jer 14,$3 ; 15,4 ; 26,17)$. 
there is no god or force outside of YHWH who can save ${ }^{34}$ and there is no power that can contest a divine decision ${ }^{35}$. For this reason, the eventuality of an intervention by idols (קבוציך) becomes ridiculous, whoever they are and whatever their number be.

Idols cannot save because they themselves are destined to an end: "all of them the wind will carry away; the breeze will take them." The wind is a natural force under the command of YHWH (Num 11,31) and is the power of God himself before which, in the moment of judgment, no idol can resist ${ }^{36}$. But הבל after all, can evoke as well that which is without strength, without consistency, vanity, for which the image is striking: those idols are so inconsistent that even a nonentity can overpower them, or simply take them away, because the idols themselves are nothing but vanity ${ }^{37}$. This description of the fate of the idols constitutes an admonition to the woman herself because whoever venerates inconsistent idols becomes like them ${ }^{38}$ and, therefore, can expect to undergo the same destiny.

\section{Conclusive antithetical framework: v. 13b}

136 But the one who takes refuge in me, he will certainly possess the land and will have for an inheritance my holy mountain.

After the last, decisive attack in vv. 12-13a, there resound yet more emphatic the final words of the divine discourse (v. 13b). Beginning with an adversative-waw, God expounds with force a new antithetical framework, having to do with both the characterization of the behavior of the unfaithful in vv. 3-13a and the destiny laid out before them in v. 6 a.

To all the acts of the people portrayed through the rebellion of children and the infidelity of a spouse God sets in opposition one sole action: to entrust oneself to the Lord. The participial form of the root havioral characteristics of the subject and omitting any other identification or characterization.

34 Idols cannot save (נצל): 2 Sam 12,21; Is 47,14; only Yhwh can save: Ps 34,8; 72,12; 107,6 .

35 Cfr. Dt 32,31.

36 The רוח as divine force in judgment: Jb 4,9; Is 30,28; 41,16; Jer 4,12; Hos 4,19.

37 Cfr. Dt 32,21; Is 41,29; Jer 2,5; 8,9; 10,15.

38 Cfr. 2 Kgs 17,15; Jer 2,5. 
To the disastrous fate hanging over the unfaithful is opposed another fate, of those who place their trust in God: this one "will certainly possess the land and will have for an inheritance my holy mountain" (the two verbs in the Impf., ינחל "יריש and, expressing declarative modality). The illocutionary force is therefore representative, since the assertion is validated both by the truth of the facts and by the authority of the speaker.

The strategic importance of v. 13b, at the close of the discourse, acquires great communicative relevance because, on the one hand, YHWH lingers on the portrayal of a possible, positive outcome stimulating his interlocutors to pursue it, and on the other hand, he presents one sole behavior that is necessary and sufficient, with the scope of convincing them that reaching this outcome is not difficult. The pragmatic force is thus amplified by the inevitable confrontation with a series of actions following upon adultery, which, despite the fatigue and undertakings involved, are not only useless in light of the outcome hoped for, but are also grotesque and counterproductive. Consequently, on the illocutionary plane, v. $13 \mathrm{~b}$ should not be interpreted as an unconditional promise of forgiveness and of the re-establishment of a relationship, but rather as the confirmation that the accusation of YHWH does not aim at condemnation, but the re-establishment of relationships.

At the conclusion of this analysis, we can better see how Is 57,3-13 - observed from a communicative point of view and according to its proper literary genre - acts upon the listeners and readers, pushing them to give their own operative response.

Since YHWH takes up the word as the offended party, in his speaking there is lacking the characteristic neutrality constitutive of forensic judgment, expressed through the mouth of a judge. The sentence pronounced by God is made manifest as a word of blame that imposes itself with the weight of his authority in stigmatizing the misdeed of the adulteress and of the unfaithful offspring and in the threat of sanction for the delicts committed. Nevertheless, in a way different from judiciary sentencing, his threat is not inevitable in its execution, but remains "conditioned" by the response of the accused. Consequently, the goal of the sanction - and of the entire divine proceedings - is not so much to punish the guilty as rather to induce them to return upon their path and see themselves again as senseless (the expected perlocutionary effects). 


\section{Referenses}

Austin J.L., How to Do Things with Words, Oxford 1962.

Bovati P., Ristabilire la giustizia, Analecta Biblica 110, Roma 1986.

Brongers H.A., "Some Remarks on the Biblical Particle halô'”, Oudtestamentische Studiën 21 (1981) 177-189.

Grilli M., Guidi M., Obara E.M., Comunicazione e pragmatica nell'esegesi biblica, Lectio 10, Roma 2016.

Irwin W.H., "The Smooth Stones of the Wady?" Isaiah 57,6, Catholic Biblical Quarterly 29 (1967) 31-40.

Lausberg H., Handbuch der literarischen Rhetorik, München 1960.

Lewis T.J., Cults of Dead in Ancient Israel and Ugarit, Harvard Semitic Monographs 39, Atlanta GA 1989.

Obara E.M., "Le azioni linguistiche: l'influsso del testo sul contesto", in M. Grilli, Guidi M., Obara E.M., Comunicazione e pragmatica nell'esegesi biblica, Lectio 10, Roma 2016, 84-117.

Pauritsch K., Die neue Gemeinde: Gott sammelt Ausgestossene und Arme (Jesaja 56-66). Die Botschaft des Tritojesaja-Buches literar-, form-, gattungskritisch und redaktiongeschichtlich untersucht, Analecta Biblica 47, Roma 1971.

Polan G.J., In the Ways of Justice Toward Salvation. A Rhetorical Analysis of Isaiah 56-59, American University Studies: Series VII. Theology and Religion, New York-Berne-Frankfurt am Main 1986.

Searle J.R., Speech-Acts. An Essay in the Philosophy of Language, Cambridge 1969.

Spronk K., Beatific Afterlife in Ancient Israel and in the Ancient Near East, Alter Orient und Altes Testament 219, Neukirchen-Vluyn 1986.

Young E.J., The Book of Isaiah, vol. III: Chapters 40 through 66, New International Biblical Commentary, Grand Rapids, MI 1969. 